\title{
What is the Value and Impact of the Adaptation Process on Quality Indicators for Local Use? A Scoping Review
}

Siyi Zhu ( $\nabla$ hxkfzsy@scu.edu.cn)

Sichuan University West China Hospital https://orcid.org/0000-0001-8213-7622

Tao Wu

Sichuan University West China Hospital

Jenny Leese

ARC: Arthritis Research Canada

Linda C. Li

ARC: Arthritis Research Canada

Chengqi He

Sichuan University West China Hospital

Lin Yang

Sichuan University West China Hospital

Research

Keywords: Quality indicators, Quality improvement, Delivery of Health Care, Consensus, Cross-cultural comparison.

Posted Date: June 1st, 2021

DOI: https://doi.org/10.21203/rs.3.rs-553164/v1

License: (c) (1) This work is licensed under a Creative Commons Attribution 4.0 International License. Read Full License 


\section{Abstract}

Background: Quality indicators (QIs) are designed for improving quality of care, but the development of Qls is resource intensive and time consuming. This study sought to describe and identify the impact and potential attributes of the adaptation process for the local use of existing QIs.

Methods: EMBASE, MEDLINE, CINAHL and grey literature were searched for literature operationalizing or implementing QIs that were developed in a different jurisdiction from the place where the QIs were use. Two reviewers independently extracted and mapped data on study and participant characteristics, the adaptation process of QIs, aims and key findings of studies, from which the attributes of the adaptation process was analysed. The quality assessment was done with the SQUIRE tool.

Results: Of 7704 citations identified, 10 out of 33 articles were included. All studies were assessed as high quality and most were from Europe. Our results revealed a lack of definition and conceptualization for a systematic adaptation processes in which an existing set of QIs was applied. Four out of ten studies involved a consensus process (e.g., Delphi or RAND process) to determine the suitability of Qls for local use. Qls for chronic conditions in primary and secondary settings were mostly used for adaptation. Of the ones that underwent a consensus process, 56.3 to $85.7 \%$ of original QIs were considered valid for local use, and 2 to $21.8 \%$ of proposed Qls were newly added. Combining all findings, four attributes should be included in a systematic approach of adaptation: 1) identification of areas/conditions for QIs adaptation and operationalization; 2) intermediate process with considerations of issues risen from adaptation; 3) introduction of a set of proposed QIs for local use; 4) operationalizing QIs and evaluating the applicability.

Conclusion: The existing QIs, although serving as a good starting point, were poorly adapted before for use in a different jurisdiction from their origin. Adaptation of QIs under a systematic approach is critical. Therefore, we propose that a systematic adaptation approach including at least four attributes found by this study should be formulated to inform future research planning for Qls adaptation and potentially establishing a new pathway for healthcare improvement.

Trial registration: PROSPERO (CRD42018096844).

\section{Background}

Performance measurement is one of the five domains involved in improving quality of care (1). Tremendous efforts have been made to investigate how and for which conditions quality deficiencies stand so as to target where improvements are needed. The Institute of Medicine defined quality of care as "the degree to which health services for individuals and populations increase the likelihood of desired health outcomes and are consistent with current professional knowledge" (2). Quality indicators (QIs) have been developed and applied to facilitate regulation, measure performance, advance accountability and improve the quality of care across countries since the 1990s. For example, Qls for patients with osteoarthritis were developed in 2004 by the Arthritis Foundation, which represent the minimal and evidence-based care that should be received by the targeted population (3). However, clinical uncertainty about practice and quality of care varies remarkably in reality. For example, divergence from evidence-based care is commonly seen in care for osteoarthritis and other conditions, where only around half of patients receive the guideline-recommended treatment (4). QIs are "standardized, evidence-based measures of healthcare quality that can be used to measure and track health status and health system performance, and characteristics across different populations, between jurisdictions, or over time" (5). Typically, QIs include statements about the structure, process and outcomes of care in the 'IF-THEN-BECAUSE' format (6, 7). The "IF" statement determines eligibility for the care process in question, the "THEN" statement specifies what care process should be performed, and the "BECAUSE" touches on the expected health impact where the indicator is implemented (8). An example of a quality indicator is as follows: "IF a patient has symptomatic osteoarthritis of the knee or hip and has been overweight for 3 years THEN he/she should receive referral to a weight loss program" (3).

Researchers in the RAND group developed a consensus method for systematically combining best evidence with expert opinion to assess the appropriateness of healthcare and lead the way in the use of QIs (9). With using a modified version of this method, QI statements specifying context structure, care process and expected outcomes are generated using the synthesized evidence. Large-scale efforts to develop and implement QIs for healthcare in many conditions have been exerted mostly in the US and Europe $(5,10-12)$. However, the development process of QIs is time-consuming and comes at a high cost, so it is reasonable for countries to use existing QIs rather than develop their own. In the US, four years between 1995 and 1999 were taken to develop the RAND QIs, while researchers in the UK adapted this set of QIs for local use in less than two years (13). Transferring QIs between countries with an intermediate process is therefore feasible, but the rate of agreement on accepting QIs for local use differed remarkably. Care of the elderly is considered as an increasingly important component in healthcare service worldwide. The Assessing Care Of Vulnerable Elderly (ACOVE) Qls were developed aiming to evaluate and optimize the care for elderly patients in US by Rand Healthcare and the UCLA (14). Several studies adapted ACOVE QIs for local use in the UK and Netherlands with an approval rate (\# of original QIs to \# of proposed QIs in the adaptation) varying from 56-86\% $(13,15,16)$. Further, there also have been examples in which QIs developed in one jurisdiction were used in another region without adaptation under a direct-adoption process $(17,18)$. An expert panel from England rated 79 of 93 chosen ACOVE QIs as valid for local use without any amendment (15). Although there are potential benefits in using an existing set of QIs as a starting point to adapt a set of QIs for local use, it is unclear what an adaptation process should involve transferring a set of QIs for local use, and whether such a process is always appropriate or desirable in adapting or applying a set of QIs. Therefore, the aim of this study was to review the literature on the process used for adapting an existing set of Ql's for local use.

\section{Methods}

A scoping review protocol was guided by the work of Arksey and O'Malley (19) and further refined by Peters Micah et al. initiated by the Joanna Briggs Institute (20). The draft protocol was revised based on feedback received from co-authors and registered in an international prospective registry of systematic reviews (PROSPERO; reference number: CRD42018096844) (21). The Preferred Reporting Items for Systematic Reviews and Meta-Analyses extension for Scoping Reviews (PRISMA-ScR) guidelines were followed (22). 
For the purpose of the review, a quality indicator was defined as a measure transformed into a statement that was validated and presented as percentage or proportion describing quality of care delivered (23). We defined an adaptation process as a standardized process that purposefully selected a set of existing QIs (with or without an intermediate process, e.g., RAND or Delphi process) and transformed them into a set that was deemed suitable for use in the local context.

\section{Search strategy}

Search strategies were developed combining terms of subject headings and text words related to concepts of QIs and adaptation processes (Supplementary materials). EMBASE, MEDLINE and CINAHL were searched from January 1990 to March 2021. A search of Google Scholar using keywords including "quality indicators", "quality improvement", "healthcare", "cross-cultural adaptation”, "transferability", and websites of quality improvement research were conducted to identify grey literature. A librarian specializing in medical information at the University of British Columbia helped revise searches. The reference lists of included studies were reviewed to identify additional eligible studies.

\section{Study selection}

Endnote X9 was used to manage citations retrieved from searches and remove duplicates. Studies were eligible if they 1) adapted or operationalized a set of existing QIs for local use; 2) assessed the acceptability or usability of adapted or operationalized QIs, with a definition of to what extent the indicator was judged as acceptable or practical for local use by those being assessed or those performing the assessment; 3 ) published in English or Chinese. Two reviewers independently conducted the level 1 (titles and abstracts) and level 2 (full text) screenings. A screening tool was developed and tested on a sample of citations retrieved prior to the full review (Supplementary materials). Any disagreement between the two was discussed and, if needed, resolved through discussion with a third party.

\section{Data collection and synthesis}

For included studies, data were extracted on study characteristics (e.g., first author, year and country of publication), participants/population description, healthcare settings, process involved in adaptation, objectives and key conclusions. Qls were classified as the original set and adapted set based on the aspects of structure, process and outcome assessed. Information on QIs used and adapted, test results where applicable and any finding related to the adaptation were reviewed and mapped. A data extraction form was developed and piloted on a sample of citations prior to the data extraction. Two reviewers were involved independently, and consensus was used to resolve any disagreements, or arbitration by a third party if applicable.

\section{Quality assessment}

The quality of included studies was assessed by two reviewers using Revised Standards for Quality Improvement Reporting Excellence (SQUIRE 2.0), a framework with 18 items for reporting new knowledge about how to improve healthcare (24). A quality score out of eighteen was given to all studies included. Two reviewers scored studies independently, and agreements were achieved by either consensus or arbitration by a third party if applicable.

\section{Results}

The search yielded 7704 articles, of which 33 articles were identified eligible for full-text screening after the removal of duplicates and review of titles and abstracts. Of these, 10 articles $(13,15-18,25-29)$ were included in this study for data extraction and synthesis, 6 of which were identified manually by authors (Fig. 1). For $90 \%$ of included studies, the primary aim was to assess acceptability of Qls transferred from one country to another with an intermediate or direct-adoption process, and one study (27)was conducted to assess quality of care by operationalizing QIs locally (Table 2). Studies were excluded because they did not involve adapting or operationalizing a set of existing QIs for local use. The main reasons for exclusion were no QI used in the study ( $\mathrm{n}=$ 9) or no adaptation process was described $(n=20)$. Of the latter, 10 were QIs development studies, eight were QIs implementation studies, and two were methodology studies.

\section{Quality of included studies}

Articles included were assessed as high-quality, with SQUIRE 2.0 scores (24) of 18/18 for 4 studies, 17/18 for 3 studies, 16/18 for 2 studies and 15/18 for one study. Ethical consideration, the description of limitation and indicating funding resources were identified as three main weaknesses in the quality assessment. The findings are summarized in Table 1. 
Table 1

Summary of the SQUIRE Statement quality appraisal results Criterion

\begin{tabular}{|c|c|c|c|c|c|c|c|c|c|c|c|c|c|c|c|c|c|c|}
\hline \multirow[t]{2}{*}{ Study } & \multicolumn{18}{|c|}{ Criterion $^{a}$} \\
\hline & 1 & 2 & 3 & 4 & 5 & 6 & 7 & 8 & 9 & 10 & 11 & 12 & 13 & 14 & 15 & 16 & 17 & 18 \\
\hline Effendy $2014^{(25)}$ & 1 & 1 & 1 & 1 & 1 & 1 & 1 & 1 & 1 & 1 & 1 & 0 & 1 & 1 & 1 & 1 & 1 & 0 \\
\hline Steel $2004^{(15)}$ & 1 & 1 & 1 & 1 & 1 & 1 & 1 & 1 & 1 & 0 & 1 & 0 & 1 & 1 & 1 & 0 & 1 & 1 \\
\hline van der Ploeg $2007^{(16)}$ & 1 & 1 & 1 & 1 & 1 & 1 & 1 & 1 & 1 & 1 & 1 & 1 & 1 & 1 & 1 & 1 & 1 & 1 \\
\hline Marshall $2003^{(13)}$ & 1 & 1 & 1 & 1 & 1 & 1 & 1 & 1 & 1 & 1 & 1 & 0 & 1 & 1 & 1 & 0 & 1 & 1 \\
\hline Jeon $2017^{(18)}$ & 1 & 1 & 1 & 1 & 1 & 1 & 1 & 1 & 1 & 1 & 1 & 1 & 1 & 1 & 1 & 1 & 1 & 1 \\
\hline Pellesi $2017^{(28)}$ & 1 & 1 & 1 & 1 & 1 & 1 & 1 & 1 & 1 & 1 & 1 & 1 & 1 & 1 & 1 & 1 & 1 & 1 \\
\hline Schramm 2016(29) & 1 & 1 & 1 & 1 & 1 & 1 & 1 & 1 & 1 & 1 & 1 & 1 & 1 & 1 & 1 & 1 & 1 & 1 \\
\hline Hansen $2013^{(17)}$ & 1 & 1 & 1 & 1 & 1 & 1 & 1 & 1 & 1 & 1 & 1 & 0 & 1 & 1 & 1 & 1 & 1 & 1 \\
\hline Katsarava $2015^{(26)}$ & 1 & 1 & 1 & 1 & 1 & 1 & 1 & 1 & 1 & 1 & 1 & 1 & 1 & 1 & 1 & 0 & 1 & 1 \\
\hline Li $2011^{(27)}$ & 1 & 1 & 1 & 1 & 1 & 1 & 1 & 1 & 1 & 1 & 1 & 1 & 1 & 1 & 1 & 1 & 1 & 0 \\
\hline \multicolumn{19}{|c|}{$\begin{array}{l}\text { a Revised Standards for Quality Improvement Reporting Excellence (SQUIRE 2.0): 1. Title; 2. Abstract; 3. Problem Description; } 4 \text {. Available knowledge; } 5 . \\
\text { Rationale; } 6 \text {. Specific aims; 7. Context; 8. Intervention(s); 9. Study of the Intervention(s); 10. Measures; } 11 \text {. Analysis; 12. Ethical Considerations; 13. Results } \\
\text { 14. Summary; 15. Interpretation; 16. Limitations; 17. Conclusions; 18. Funding. }\end{array}$} \\
\hline
\end{tabular}

\section{Study characteristics}

Table 2 summarizes the characteristics of studies included in the study. The years of publication ranged from 2002 to 2017 . Seven out of 10 studies were undertaken in Europe including the UK (2), European consortium (2), Netherlands (1), Denmark (1) and Italy (1). Two studies (18, 25)were from Asia-Pacific regions and one was from Canada. The participants involved in included studies varied with respect to clinical disciplines and how Qls were adapted. These disciplines included geriatric medicine (3), headache conditions (3), palliative care (1), mental health (1), respiratory medicine (1) and rheumatology (1). Four studies $(13,15,16,25)$ formed a multi-disciplinary expert panel to assess the transferability of Qls between countries through an intermediate process supported by the RAND/UCLA and Delphi methods. Other studies tested the QIs in at least one target population in which the QIs were originally developed. These included health care professionals, health services managers, and patients. The acceptability of QIs was also assessed by reviewing medical records or results of surveys in the latter group of studies included. For the setting where QIs were adapted, six studies were conducted in the general practice setting or primary and secondary settings, others were conducted in the secondary or tertiary setting. 
Table 2

Study Characteristics

\begin{tabular}{|c|c|c|c|c|c|c|}
\hline $\begin{array}{l}\text { First } \\
\text { author } \\
\text { (Year) }\end{array}$ & $\begin{array}{l}\text { Country of } \\
\text { publication }\end{array}$ & Population/participants description & Settings & $\begin{array}{l}\text { Steps involved } \\
\text { in employing } \\
\text { quality } \\
\text { indicators }\end{array}$ & Aim of the study & Key Conclusion \\
\hline $\begin{array}{l}\text { Effendy } \\
2014^{(25)}\end{array}$ & Indonesia & $\begin{array}{l}12 \text { experts in palliative care or cancer care } \\
\text { and } 12 \text { additional experts involved in a } \\
\text { multidisciplinary panel. }\end{array}$ & $\begin{array}{l}\text { Palliative } \\
\text { care in } \\
\text { hospital } \\
\text { setting }\end{array}$ & $\begin{array}{l}\text { Modified RAND } \\
\text { Delphi process }\end{array}$ & $\begin{array}{l}\text { 1) Face-validate an } \\
\text { Indonesian set of } \\
\text { Qls based on a } \\
\text { European set; 2) } \\
\text { Compare and test } \\
\text { the applicability of } \\
\text { Indonesian set. }\end{array}$ & $\begin{array}{l}\text { Most of the } \\
\text { European set were } \\
\text { face-valid and } \\
\text { applicable in } \\
\text { Indonesian } \\
\text { hospitals. }\end{array}$ \\
\hline $\begin{array}{l}\text { Steel } \\
2004^{(15)}\end{array}$ & UK & $\begin{array}{l}\text { An expert panel consisted of } 6 \text { consultant } \\
\text { physicians in geriatric medicine or } \\
\text { medicine for the elderly, } 3 \text { general } \\
\text { practitioners, and } 1 \text { nurse. }\end{array}$ & $\begin{array}{l}\text { Primary } \\
\text { and } \\
\text { secondary } \\
\text { care setting }\end{array}$ & $\begin{array}{l}\text { RAND/UCLA } \\
\text { appropriateness } \\
\text { method }\end{array}$ & $\begin{array}{l}\text { 1) Adapt a set of } \\
\text { USA quality } \\
\text { indicators in } \\
\text { England; } 2 \text { ) Measure } \\
\text { the extent to which } \\
\text { older patients } \\
\text { receive a broad } \\
\text { range of effective } \\
\text { healthcare } \\
\text { interventions. }\end{array}$ & $\begin{array}{l}\text { These } 102 \\
\text { indicators are } \\
\text { suitable for use in } \\
\text { patient interview } \\
\text { surveys in England, } \\
\text { and there is } \\
\text { potential for transfer } \\
\text { of quality indicators } \\
\text { between countries. }\end{array}$ \\
\hline $\begin{array}{l}\text { van der } \\
\text { Ploeg } \\
2007^{(16)}\end{array}$ & Netherlands & $\begin{array}{l}\text { A panel consisted of } 8 \text { general } \\
\text { practitioners, } 2 \text { nursing-home } \\
\text { practitioners and } 2 \text { clinical geriatricians. }\end{array}$ & $\begin{array}{l}\text { General } \\
\text { practice } \\
\text { care }\end{array}$ & $\begin{array}{l}\text { RAND/UCLA } \\
\text { process }\end{array}$ & $\begin{array}{l}\text { 1) Adapt a set of } \\
\text { USA quality } \\
\text { indicators in } \\
\text { Netherlands; 2) Test } \\
\text { the transferability of } \\
\text { quality indicators } \\
\text { between countries. }\end{array}$ & $\begin{array}{l}\text { Quality indicators } \\
\text { can be transferred } \\
\text { between countries } \\
\text { but with caution. }\end{array}$ \\
\hline $\begin{array}{l}\text { Marshall } \\
2003^{(13)}\end{array}$ & UK & $\begin{array}{l}\text { Two panels of UK general practitioners } \\
\text { were recruited from } 196 \text { doctors, of which } \\
75 \% \text { agreed to take part. Nine members } \\
\text { for each of two panels were selected } \\
\text { purposely. }\end{array}$ & $\begin{array}{l}\text { General } \\
\text { practice } \\
\text { care }\end{array}$ & $\begin{array}{l}\text { RAND/UCLA } \\
\text { process }\end{array}$ & $\begin{array}{l}\text { Evaluate the } \\
\text { transferability of } \\
\text { primary care quality } \\
\text { indicators developed } \\
\text { using the same } \\
\text { method between the } \\
\text { UK and the USA. }\end{array}$ & $\begin{array}{l}\text { Considerable } \\
\text { benefits using work } \\
\text { from other settings } \\
\text { are presented for } \\
\text { developing } \\
\text { measures of quality } \\
\text { of care, but } \\
\text { indicators should } \\
\text { not be transferred } \\
\text { between countries } \\
\text { without adaptation. }\end{array}$ \\
\hline $\begin{array}{l}\text { Jeon } \\
2017^{(18)}\end{array}$ & $\begin{array}{l}7 \text { Asia- } \\
\text { Pacific } \\
\text { countries }\end{array}$ & $\begin{array}{l}\text { Member country representatives of the } \\
\text { PROMOTE (Psychosocial Research } \\
\text { Consortium to Advance Mental Health of } \\
\text { Older People in the Asia-Pacific region). } \\
\text { Medical records of } 275 \text { residents with } \\
\text { dementia were extracted. }\end{array}$ & $\begin{array}{l}\text { Institutional } \\
\text { or long- } \\
\text { term care } \\
\text { setting }\end{array}$ & Not applicable & $\begin{array}{l}\text { Determine whether } \\
\text { or not European } \\
\text { quality indicators } \\
\text { (QIs) for } \\
\text { psychosocial care in } \\
\text { dementia could be } \\
\text { implemented across } \\
\text { seven Asia-Pacific } \\
\text { countries. }\end{array}$ & $\begin{array}{l}\text { Several indicators in } \\
\text { the European set } \\
\text { were problematic } \\
\text { with the direct } \\
\text { adoption in Asia- } \\
\text { Pacific region, and } \\
\text { refinements of the } \\
\text { original set are } \\
\text { required in future. }\end{array}$ \\
\hline $\begin{array}{l}\text { Pellesi } \\
2017^{(28)}\end{array}$ & Italy & $\begin{array}{l}\text { Six headache specialist centres were } \\
\text { recruited via a network of young Italian } \\
\text { researchers on headache. Service records } \\
\text { from the physicians and other HCPs } \\
\text { (nurses, psychologists and/or nursing } \\
\text { assistants) involved in outpatient } \\
\text { consultations, and from } 60 \text { consecutive } \\
\text { patients were extracted. }\end{array}$ & $\begin{array}{l}\text { Headache } \\
\text { specialist } \\
\text { centres } \\
\text { (level 3) }\end{array}$ & Not applicable & $\begin{array}{l}\text { Extend } \\
\text { implementation of } \\
\text { quality indicators } \\
\text { and examine } \\
\text { acceptability and } \\
\text { ease of use of the } \\
\text { assessment } \\
\text { instrument in Italian } \\
\text { specialist headache } \\
\text { centres. }\end{array}$ & $\begin{array}{l}\text { This Italy-wide } \\
\text { survey confirmed in } \\
\text { six specialist centres } \\
\text { that the headache } \\
\text { service quality } \\
\text { indicators are fit for } \\
\text { purpose. }\end{array}$ \\
\hline $\begin{array}{l}\text { Schramm } \\
2016^{(29)}\end{array}$ & $\begin{array}{l}12 \\
\text { countries in } \\
\text { Europe }\end{array}$ & $\begin{array}{l}\text { Service staff and patients were study } \\
\text { participants. The patient participants at } \\
\text { each centre were a prospective } \\
\text { consecutive sample }(n=50) \text {. In addition, } \\
\text { information was acquired from the } \\
\text { records of a retrospective random or } \\
\text { consecutive sample of } 50 \text { patients. }\end{array}$ & $\begin{array}{l}\text { Secondary } \\
\text { (level-2) or } \\
\text { tertiary } \\
\text { (level-3) } \\
\text { headache } \\
\text { clinics }\end{array}$ & Not applicable & $\begin{array}{l}\text { Evaluate the } \\
\text { implementation of } \\
\text { quality indicators for } \\
\text { headache care } \\
\text { Europe-wide in } \\
\text { specialist headache } \\
\text { centres }\end{array}$ & $\begin{array}{l}\text { The quality } \\
\text { indicators were } \\
\text { workable in } \\
\text { specialist care } \\
\text { across Europe. }\end{array}$ \\
\hline $\begin{array}{l}\text { Hansen } \\
2013^{(17)}\end{array}$ & Denmark & $\begin{array}{l}102 \text { Danish general practitioners } \\
\text { accepted to participate. }\end{array}$ & $\begin{array}{l}\text { General } \\
\text { Practice } \\
\text { care }\end{array}$ & Not applicable & $\begin{array}{l}\text { Assess a set of } 41 \\
\text { newly developed } \\
\text { international quality } \\
\text { indicators for } \\
\text { antibiotic treatment } \\
\text { of respiratory tract } \\
\text { infections. }\end{array}$ & $\begin{array}{l}\text { Only a few of the set } \\
\text { of quality indicators } \\
\text { developed by } \\
\text { international panel } \\
\text { were rated suitable } \\
\text { by the GPs. }\end{array}$ \\
\hline
\end{tabular}




\begin{tabular}{|c|c|c|c|c|c|c|}
\hline $\begin{array}{l}\text { First } \\
\text { author } \\
\text { (Year) }\end{array}$ & $\begin{array}{l}\text { Country of } \\
\text { publication }\end{array}$ & Population/participants description & Settings & $\begin{array}{l}\text { Steps involved } \\
\text { in employing } \\
\text { quality } \\
\text { indicators }\end{array}$ & Aim of the study & Key Conclusion \\
\hline $\begin{array}{l}\text { Katsarava } \\
2015^{(26)}\end{array}$ & $\begin{array}{l}\text { Germany } \\
\text { and } \\
\text { Portugal }\end{array}$ & $\begin{array}{l}\text { In each centre the health professionals } \\
\text { most involved in delivering the service } \\
\text { were interviewed, and consecutive } \\
\text { patients and their records were } \\
\text { investigated. Numbers of patients at each } \\
\text { centre were determined by what was } \\
\text { feasible. }\end{array}$ & $\begin{array}{l}\text { Primary } \\
\text { and } \\
\text { secondary } \\
\text { headache } \\
\text { clinics }\end{array}$ & Not applicable & $\begin{array}{l}\text { Evaluate the } \\
\text { feasibility and } \\
\text { acceptability of } \\
\text { quality indicators in } \\
\text { the two countries. }\end{array}$ & $\begin{array}{l}\text { This pilot study to } \\
\text { assess feasibility of } \\
\text { the methods and } \\
\text { acceptability of the } \\
\text { instruments of } \\
\text { headache service } \\
\text { quality evaluation } \\
\text { was successful. }\end{array}$ \\
\hline $\begin{array}{l}\mathrm{Li} \\
2011^{(27)}\end{array}$ & Canada & $\begin{array}{l}\text { Patients with hip and/or knee } \\
\text { osteoarthritis }(O A) \text { who participated in a } \\
\text { population-based survey }(n=1,349) \text {. They } \\
\text { were from a random sample of } 6000 \\
\text { patients identified using administrative } \\
\text { databases collected by the Ministry of } \\
\text { Health of British Columbia, for the } \\
\text { purpose of reimbursements for outpatient } \\
\text { physician visits and hospitalizations. }\end{array}$ & $\begin{array}{l}\text { Outpatient } \\
\text { and } \\
\text { inpatient } \\
\text { setting }\end{array}$ & Not applicable & $\begin{array}{l}\text { To assess the } \\
\text { quality of } \\
\text { nonpharmacological } \\
\text { care received by } \\
\text { people with knee } \\
\text { and/or hip } \\
\text { osteoarthritis (OA) in } \\
\text { the community and } \\
\text { to assess the } \\
\text { associated factors. }\end{array}$ & $\begin{array}{l}\text { The quality of } \\
\text { nonpharmacological } \\
\text { care for people with } \\
\text { knee/hip OA in the } \\
\text { community is } \\
\text { suboptimal. }\end{array}$ \\
\hline
\end{tabular}

\section{Adaptation of quality indicators}

Table 3 maps the use of existing QIs, with or without adaptation. Seven separate sets of original Qls were employed in the included studies, of which three were from the USA, two were from Europe, and two were developed by an international consortium. Of these existing QIs targeted, the process domain was covered in all studies, the structure domain was addressed in four studies, while one study addressed the outcome domain. 
Table 3

Adaptation of Quality Indicators (QIs)

\begin{tabular}{|c|c|c|c|c|c|c|c|c|c|c|c|}
\hline \multirow[t]{2}{*}{ Ref } & \multirow{2}{*}{$\begin{array}{l}\text { Original set } \\
\text { of Qls }\end{array}$} & \multirow{2}{*}{$\begin{array}{l}\text { Country of } \\
\text { the original } \\
\text { set }\end{array}$} & \multirow{2}{*}{$\begin{array}{l}\text { Country of } \\
\text { the } \\
\text { adaptation }\end{array}$} & \multirow{2}{*}{$\begin{array}{l}\text { Qls } \\
\text { Classification }\end{array}$} & \multicolumn{7}{|c|}{ Qls adapted (N) } \\
\hline & & & & & $\begin{array}{l}\text { Proposed } \\
\text { in total }\end{array}$ & $\begin{array}{l}\text { Original } \\
\text { set }\end{array}$ & $\begin{array}{l}\text { Newly } \\
\text { added }\end{array}$ & Valid & $\begin{array}{l}\text { Significantly } \\
\text { changed }\end{array}$ & Discarded & $\begin{array}{l}\text { Apprc } \\
\text { rate c } \\
\text { propc } \\
\text { Qls }\end{array}$ \\
\hline $\begin{array}{l}\text { Effendy } \\
2014^{(25)}\end{array}$ & $\begin{array}{l}\text { A set of QIs } \\
\text { for the } \\
\text { organization } \\
\text { of palliative } \\
\text { care, } \\
\text { previously } \\
\text { developed in } \\
\text { the European } \\
\text { Europall } \\
\text { project }\end{array}$ & $\begin{array}{l}\text { Seven } \\
\text { European } \\
\text { countries }\end{array}$ & Indonesia & $\begin{array}{l}\text { Structure, } \\
\text { Process }\end{array}$ & 100 & 98 & 2 & 78 & N/A & 22 & $78.0 \%$ \\
\hline $\begin{array}{l}\text { Steel } \\
2004^{(15)}\end{array}$ & $\begin{array}{l}\text { Assessing } \\
\text { the Care of } \\
\text { Vulnerable } \\
\text { Elders } \\
\text { (ACOVE) }\end{array}$ & USA & UK & Process & 119 & 93 & 26 & 102 & N/A & 17 & $85.7 \%$ \\
\hline $\begin{array}{l}\text { van der } \\
\text { Ploeg } \\
2007^{(16)}\end{array}$ & ACOVE-3 & USA & Netherlands & Process & 113 & 108 & 5 & 77 & 4 & 32 & $68.1 \%$ \\
\hline $\begin{array}{l}\text { Marshall } \\
2003^{(13)}\end{array}$ & $\begin{array}{l}\text { The RAND } \\
\text { quality } \\
\text { indicators } \\
\text { (termed the } \\
\text { "QA tools") }\end{array}$ & USA & UK & Process & 174 & 174 & N/A & 98 & N/A & 76 & $56.3 \%$ \\
\hline $\begin{array}{l}\text { Jeon } \\
2017^{(18)}\end{array}$ & $\begin{array}{l}\text { A set of } 12 \\
\text { Qls } \\
\text { developed by } \\
\text { a } \\
\text { multinational } \\
\text { European } \\
\text { consortium }\end{array}$ & Europe & $\begin{array}{l}\text { Asia-Pacific } \\
\text { region }\end{array}$ & Process & 12 & 12 & N/A & $\mathrm{N} / \mathrm{A}$ & N/A & N/A & N/A \\
\hline $\begin{array}{l}\text { Pellesi } \\
2017^{(28)}\end{array}$ & $\begin{array}{l}\text { A set of } 30 \\
\text { Qls } \\
\text { developed by } \\
\text { Lifting the } \\
\text { Burden (LTB) }\end{array}$ & UK/WHO & Italy & $\begin{array}{l}\text { Structure, } \\
\text { Process and } \\
\text { Outcome }\end{array}$ & 30 & 30 & N/A & $\mathrm{N} / \mathrm{A}$ & N/A & N/A & N/A \\
\hline $\begin{array}{l}\text { Schramm } \\
2016^{(29)}\end{array}$ & $\begin{array}{l}\text { A set of } 30 \\
\text { Qls } \\
\text { developed by } \\
\text { Lifting the } \\
\text { Burden (LTB) }\end{array}$ & UK/WHO & Europe & $\begin{array}{l}\text { Structure, } \\
\text { Process and } \\
\text { Outcome }\end{array}$ & 30 & 30 & $\mathrm{~N} / \mathrm{A}$ & $\mathrm{N} / \mathrm{A}$ & $\mathrm{N} / \mathrm{A}$ & $\mathrm{N} / \mathrm{A}$ & N/A \\
\hline $\begin{array}{l}\text { Hansen } \\
2013^{(17)}\end{array}$ & $\begin{array}{l}\text { A set of } 41 \\
\text { Qls } \\
\text { developed by } \\
\text { a } \\
\text { international } \\
\text { consortium }\end{array}$ & International & Denmark & Process & 41 & 41 & N/A & $\mathrm{N} / \mathrm{A}$ & N/A & N/A & N/A \\
\hline
\end{tabular}




\begin{tabular}{|c|c|c|c|c|c|c|c|c|c|c|c|}
\hline \multirow[t]{2}{*}{ Ref } & \multirow{2}{*}{$\begin{array}{l}\text { Original set } \\
\text { of Qls }\end{array}$} & \multirow{2}{*}{$\begin{array}{l}\text { Country of } \\
\text { the original } \\
\text { set }\end{array}$} & \multirow{2}{*}{$\begin{array}{l}\text { Country of } \\
\text { the } \\
\text { adaptation }\end{array}$} & \multirow{2}{*}{$\begin{array}{l}\text { Qls } \\
\text { Classification }\end{array}$} & \multicolumn{7}{|c|}{ Qls adapted $(\mathrm{N})$} \\
\hline & & & & & $\begin{array}{l}\text { Proposed } \\
\text { in total }\end{array}$ & $\begin{array}{l}\text { Original } \\
\text { set }\end{array}$ & $\begin{array}{l}\text { Newly } \\
\text { added }\end{array}$ & Valid & $\begin{array}{l}\text { Significantly } \\
\text { changed }\end{array}$ & Discarded & $\begin{array}{l}\text { Apprc } \\
\text { rate C } \\
\text { propc } \\
\text { Qls }\end{array}$ \\
\hline $\begin{array}{l}\text { Katsarava } \\
2015^{(26)}\end{array}$ & $\begin{array}{l}\text { A set of } 30 \\
\text { Qls } \\
\text { developed by } \\
\text { Lifting the } \\
\text { Burden (LTB) }\end{array}$ & UK/WHO & $\begin{array}{l}\text { Germany } \\
\text { and } \\
\text { Portugal }\end{array}$ & $\begin{array}{l}\text { Structure, } \\
\text { Process and } \\
\text { Outcome }\end{array}$ & 30 & 30 & $\mathrm{~N} / \mathrm{A}$ & N/A & $\mathrm{N} / \mathrm{A}$ & $\mathrm{N} / \mathrm{A}$ & N/A \\
\hline $\begin{array}{l}\mathrm{Li} \\
2011^{(27)}\end{array}$ & $\begin{array}{l}\text { Arthritis } \\
\text { Foundation } \\
\text { Qls for } \\
\text { Osteoarthritis } \\
\text { (OA) }\end{array}$ & USA & Canada & Process & 4 & 14 & $\mathrm{~N} / \mathrm{A}$ & N/A & $\mathrm{N} / \mathrm{A}$ & $\mathrm{N} / \mathrm{A}$ & N/A \\
\hline
\end{tabular}

The total number of proposed QIs across included studies ranged from 4 to 174, which combined the original set and newly added Qls. Three studies included new QIs in addition to the original set, which accounted for 2 to $21.8 \%$ in proposed QIs. After the adaptation process involved in four included studies, at least half of proposed QIs were approved as valid for use, and the range of approval rate for proposed QIs was 56.3 to $85.7 \%$, which indicated that 17 to 76 of QIs were discarded in the process. Of these QIs proposed, 51-98 QIs of the original set were nearly identical without any change, and only 4 QIs were reported to be adapted with major changes $(16)$. Only two studies $(13,16)$ reported reasons or provided some comments on why QIs were discarded or changed in the adaptation. Figure 2 maps reasons or comments discarding or changing a QIs in the adaptation.

For the four studies $(13,15,16,25)$, only one study reported that transferability of the existing QIs was feasible, otherwise several issues including cultural context, practice difference, methodological issues, etc., should be considered in the adaptation process. None of these studies formulated a systematic or consistent adaptation approach addressing issues risen from the adaptation process. On the other hand, for six studies that did not adopt an adaptation process, all of them operationalized the existing QIs without any change. Three of the six studies reported that original QIs were easy to apply and acceptable, accounting for over an $80 \%$ approval rate for each QI used, and one reported that QIs were operationalized in assessing the quality of care, while two studies found that QIs without adaptation were not fully acceptable. Similar to studies adopting an adaptation process, issues included structure difference, different interpretation of QIs and cross-cultural validation should also be further considered in the adaptation process while operationalizing QIs. Figure 2 maps main issues mentioned in studies that may potentially affect the process of adapting Qls for local use.

We mapped attributes of the adaptation process in Fig. 2. A systematic approach of adaptation essentially included four attributes, which were 1) identification of areas/conditions for indicator adaptation and operationalization; 2) intermediate process with combinations and considerations of components listed in Fig. 2; 3) introduction of a set of proposed indicators for local use; 4) operationalizing QIs adapted with the aim to evaluate the applicability of them.

\section{Discussion}

The scoping review was conducted to specifically examine evidence adapting or operationalizing an existing set of Qls for local use. Our results highlight the essential role and four attributes of the adaptation process in transferring QIs between countries and different healthcare settings. Four out of ten included studies involved using a consensus process like RAND/UCLA and Delphi for evaluating the acceptability or usability of QIs for local use. The remaining six studies operationalized QIs by involving a multi-disciplinary staff team in medical records to assess validity and acceptability of these measures without an adaptation process. Most studies with good quality reporting were from European countries and involved Qls developed and implemented within similar settings. However, remarkable variability of how to apply an existed set of Qls locally was observed, relating to the lack of a systematic adaptation approach in adapting and operationalizing the existing QIs, which justified the necessity of the adaptation.

To apply QIs developed in a certain setting or condition, adaptation for the local context and a specific purpose, even within one country, is needed and should be conducted in a systematic manner (30). However, the absence of a standard and systematic adaptation approach process posed challenges in retrieving citations from databases. Therefore, we found that very few studies applied existing QIs, considered as a useful evidence-based quality improvement tool, outside where that were developed. About $62 \%$ of the articles were excluded in this study due to the involvement of developing and implementing QIs on their own resources and at high cost (13). Specifically, the development of several sets of Qls for populations with osteoarthritis were duplicate efforts addressing the assessment of the same process, like weight management recommendations that patients should receive from physicians (31).

Similar to the development process, the adaptation process should ideally take place in an iterative way combining inputs from researchers and other stakeholders (32). Based on what we found in this study, we proposed a systematic approach with four potential attributes should be addressed during the adaptation process. First of all, areas/conditions of interest for Qls adaptation should be targeted. With reference to the adaptation and cross-validation of the US Primary Care Assessment Scales in different countries (33-36), several steps should be taken in the intermediate process, which include but not limited to 1) identification of original set of QIs; 2) an expert panel and user focus group; 3) consensus techniques (e.g. Delphi process, RAND/UCLA, Nominal Group 
Technique process); 4) review of QIs wording for local use;. Although the review of scientific evidence is not imperative in the adaptation process, it served to promote mutual understanding across different contexts, and inform the development and adaptation process. After the introduction of a set of proposed QIs for local use, the degree to which Qls have been approved needs to be assessed by the rigorous method validated in the development process to facilitate decision making (37).

Furthermore, several issues risen from the existing evidence should be taken into account during the intermediate process for the adaptation of Qls. In our study, we found that the approval rate of QIs involved in included studies ranged from 56.3 to $85.7 \%$, and no study could conclude that introducing existing QIs without adaptation was just a matter of copy and paste (30). Marshall et al. (13) and van der Ploeg et al. (16), adapted US QIs for local use in the UK and Netherlands separately, both indicated that issues like differences in professional practice, expert opinion, panel process, integration of literature source and healthcare context often lead to controversy and inconsistency in the approval of Qls for local use in two countries. For example, they found that the body of evidence reviewed by US researchers differed in content and literature source from that conducted in the UK and Netherlands, for which some QIs were discarded by panellists. In addition, the information infrastructure used to extract data and test the indicator and healthcare systems are different in different regions (30). Several studies included in this study stated that regional and contextual variations in the structure and process of healthcare systems are major contributors to the failure of directly adopting QIs without any adaptation. In Asia-Pacific countries, more than half of 12 European QIs for dementia were found to be problematic to be used in residential long-term facilities which were different settings for which the QIs were applied (18).

On the other hand, contextual factors should be emphasized at the start of identification of an areas or conditions of interests for QIs adaptation. In the conceptual model of health care, although outcomes are of greatest interest to patients, improving process and how process improves outcomes become the primary target for quality improvement $(23,37,38)$. Process QIs were found in all included studies of this review, supported by findings that the volume of process QIs in The National Quality Measure Clearinghouse increased almost 10 times in a decade between 2003-2013 (23). Process measurement of healthcare involving QIs has become increasingly common practice and a statutory obligation for administrations worldwide to identify gaps, advance decision-making and inform healthcare policy and delivery $(39,40)$. In our study, we found studies in both primary and secondary care settings (17). Consistent with current knowledge of the development and implementation of QIs, QIs are mostly designed for preventive care and care for chronic conditions, and there is a paucity of QIs for emergency outbreak and infectious diseases (37). For example, the Coronavirus disease 2019 (Covid-19) pandemic has demonstrated health systems failure in terms of outbreak preparedness and coping with a sudden surge in demand for services such as acute care and rehabilitation service (41). How to provide patients infected by Covid-19 or not with a consistent level of care poses great challenges on healthcare systems during the pandemic and beyond. Therefore, adaptation of QIs in intensive care units and respiratory medicine and implementation of them in the response to Covid-19 may provide for enormous opportunities to reshape the healthcare delivery system $(42,43)$.

\section{Strengths and limitations}

The study has several strengths. First, our scoping review was conducted in compliance with the guidance endorsed by the Joanna Briggs Institute (20), and supported by a research librarian with expertise in search strategy development and evidence synthesis. Second, our review serves as a good starting point to provide data on using and adapting existing QIs for local use, in order to inform policy makers, healthcare professionals and other stakeholders in how to introduce a set of QIs in a cost-effective manner. Third, the need for adaptation of existing QIs for local use was identified by the findings of this study, which will inform future research on this topic. Lastly, we worked closely with a multidisciplinary and cross-cultural research team in conducting the review and interpreting the findings.

It is worth noting that some limitations exist in this study. First, the quality of studies may not be appropriately assessed by SQUIRE 2.0 as the checklist is intended for reports that describe system level work and establish observed outcomes due to interventions, although quality assessment of studies is not required for a scoping review. Second, studies published only in English or Chinese were searched in this study by which all relevant studies may not be identified. Third, the lack of a systematic adaptation approach for QIs may have excluded some relevant studies.

\section{Conclusions}

Evidence gaps and future research trends are identified by conducting a scoping review (with at least 10 studies available on a specific topic) like this (44). In summary, existing QIs serve as a good starting point for introducing a set of Qls for local use, while we found QIs developed in different contexts for different purposes were poorly adapted before being applied and operationalized in other settings. Adaptation of QIs under a systematic approach is critical for local use, and our review firstly identifies four attributes of a systematic adaptation approach, combined with several issues need to be addressed during the adaptation, to inform future research planning for QIs adaptation. In the future, adaptation of Qls in a systematic manner may potentially provide policy makers, care providers, stakeholders and patients with a new pathway to initiate quality improvement in healthcare and gradually reshape healthcare systems.

\section{Abbreviations}

\section{ACOVE}

Assessing Care Of Vulnerable Elderly

PROSPERO

International Prospective Registry of Systematic Reviews

PRISMA-ScR

Preferred Reporting Items for Systematic Reviews and Meta-Analyses extension for Scoping Reviews

QIs

Quality Indicators 
SQUIRE

Standards for Quality Improvement Reporting Excellence

UCLA

University of California, Los Angeles

UK

United Kingdom

US

United States

\section{Declarations}

\section{Acknowledgements}

The authors are grateful for Charlotte Beck in helping develop and revise search strategies, Clayon Hamilton, Halima Elmi, other colleagues and patient partners from Arthritis Research Canada for providing critical comments on study design.

\section{Authors' contributions}

SZ, LL and CH have made substantial contributions to the study design. JL, LY and TW have contributed to the ongoing data collection. All listed authors have contributed to the drafting of the manuscript.

\section{Funding}

This study is supported by the National Natural Science Foundation (81972146 to Chengqi He, and 82002393 to Siyi Zhu), the Department of Science and Technology of Sichuan Province (2020YJ0210 to Chengqi He, 2021 YFS0004 and 2021 YJ0424 to Siyi Zhu), China Postdoctoral Science Foundation (2020M673251), Health Commission of Sichuan Province (20PJ034), and West China Hospital of Sichuan University (HX-2019-nCoV-011 to Chengqi He, and 2019 HXBH058 to Siyi Zhu). The funders played no role in the design, conduct, or reporting of this study.

\section{Availability of Data and Materials}

Not applicable

\section{Ethics approval and consent to participate}

Not applicable.

\section{Consent for publication}

Not applicable.

\section{Competing interests}

The authors declare that they have no competing interests.

\section{References}

1. Batalden PB, Davidoff F. What is "quality improvement" and how can it transform healthcare? BMJ Publishing Group Ltd; 2007.

2. Health UDo, Services H. National healthcare disparities report. Rockville: Agency for Healthcare Research and Quality; 2003.

3. MacLean CH, Saag KG, Solomon DH, Morton SC, Sampsel S, Klippel JH. Measuring quality in arthritis care: methods for developing the Arthritis Foundation's quality indicator set. Arthritis Care Res. 2004;51(2):193-202.

4. Hunter DJ, Neogi T, Hochberg MC. Quality of osteoarthritis management and the need for reform in the US. Arthritis Care Res. 2011;63(1):31-8.

5. Farquhar M. AHRQ quality indicators. 2008.

6. Lohr KN. Medicare: a strategy for quality assurance. National Academies Press; 1990.

7. Lohr KN, Schroeder SA. A strategy for quality assurance in Medicare. N Engl J Med. 1990;322(10):707-12.

8. Ganz DA, Chang JT, Roth CP, Guan M, Kamberg CJ, Niu F, et al. Quality of osteoarthritis care for community-dwelling older adults. Arthritis Care Research: Official Journal of the American College of Rheumatology. 2006;55(2):241-7.

9. Brook RH, Chassin MR, Fink A, Solomon DH, Kosecoff J, Park RE. A method for the detailed assessment of the appropriateness of medical technologies. Int J Technol Assess Health Care. 1986;2(1):53-63.

10. Arah OA, Westert GP, Hurst J, Klazinga NS. A conceptual framework for the OECD health care quality indicators project. Int J Qual Health Care. 2006;18(suppl_1):5-13.

11. Doran T, Fullwood C, Gravelle H, Reeves D, Kontopantelis E, Hiroeh U, et al. Pay-for-performance programs in family practices in the United Kingdom. N Engl J Med. 2006;355(4):375-84.

12. Kramers PG. The ECHI project: health indicators for the European Community. The European Journal of Public Health. 2003;13(suppl_1):101-6. 
13. Marshall MN, Shekelle PG, McGlynn Ea, Campbell S, Brook RH, Roland MO. Can health care quality indicators be transferred between countries? Quality $\backslash$ \& safety in health care. 2003;12(1):8-12.

14. Wenger NS, Shekelle PG. Assessing care of vulnerable elders: ACOVE project overview. Ann Intern Med. 2001;135(8_Part_2):642-6.

15. Steel N, Melzer D, Shekelle PG, Wenger NS, Forsyth D, McWilliams BC. Developinq quality indicators for older adults: Transfer from the USA to the UK is feasible. Quality Safety in Health Care. 2004;13(4):260-4.

16. van der Ploeg E, Depla MFla, Shekelle P, Rigter H, Mackenbach JP. Developing quality indicators for general practice care for vulnerable elders; transfer from US to The Netherlands. Quality $\backslash \&$ safety in health care. 2008;17(4):291-5.

17. Hansen MP, Bjerrum L, Gahrn-Hansen B, Christensen RDP, Davidsen JR, Munck A, et al. Quality indicators for treatment of respiratory tract infections? An assessment by Danish general practitioners. European Journal of General Practice. 2013;19(2):85-91.

18. Jeon Y-H, Chien WT, Ha J-Y, Ibrahim R, Kirley B, Tan LL, et al. Application of the European quality indicators for psychosocial dementia care in long-term care facilities in the Asia-Pacific region: a pilot study. Aging \\& Mental Health. 2017;0(0):1-8.

19. Arksey H, O'Malley L. Scoping studies: towards a methodological framework. Int J Soc Res Methodol. 2005;8(1):19-32.

20. Peters MD, Marnie C, Tricco AC, Pollock D, Munn Z, Alexander L, et al. Updated methodological guidance for the conduct of scoping reviews. JBI Evidence Synthesis. 2020;18(10):2119-26.

21. Siyi Z, Linda L, Chengqi H. The effects of the active adaption process on the suitability and usability of existing QIs for local use. PROSPERO 2018 CRD42018096844 2021 [Available from: https://www.crd.york.ac.uk/prospero/display_record.php?ID=CRD42018096844.

22. Tricco AC, Lillie E, Zarin W, O'Brien KK, Colquhoun H, Levac D, et al. PRISMA extension for scoping reviews (PRISMA-ScR): checklist and explanation. Ann Intern Med. 2018;169(7):467-73.

23. Shekelle PG. Quality indicators and performance measures: methods for development need more standardization. J Clin Epidemiol. 2013;66(12):1338.

24. Ogrinc G, Davies L, Goodman D, Batalden P, Davidoff F, Stevens D. SQUIRE 2.0 (Standards for QUality Improvement Reporting Excellence): revised publication guidelines from a detailed consensus process. Am J Crit Care. 2015;24(6):466-73.

25. Effendy C, Vissers K, Woitha K. Face-validation of quality indicators for the organization of palliative care in hospitals in Indonesia: a contribution to quality improvement. Support Care Cancer. 2014;22(12):3301-10.

26. Katsarava Z, Gouveia RG, Jensen R, Gaul C, Schramm S, Schoppe A, et al. Evaluation of headache service quality indicators: pilot implementation in two specialist-care centres. Journal of Headache Pain. 2015;16(1):1-8.

27. Li LC, Sayre EC, Kopec JA, Esdaile JM, Bar S, Cibere J. Quality of nonpharmacological care in the community for people with knee and hip osteoarthritis. J Rheumatol. 2011;38(10):2230-7.

28. Pellesi L, Benemei S, Favoni V, Lupi C, Mampreso E, Negro A, et al. Quality indicators in headache care: an implementation study in six Italian specialistcare centres. Journal of Headache and Pain. 2017;18(1).

29. Schramm S, Uluduz D, Gouveia RG, Jensen R, Siva A, Uygunoglu U, et al. Headache service quality: evaluation of quality indicators in 14 specialist-care centres. The Journal of Headache and Pain. 2016.

30. Delnoij DM, Westert GP. Assessing the validity of quality indicators: keep the context in mind! Oxford University Press; 2012.

31. Strömbeck B, Petersson IF, Vliet Vlieland TP, group EnW. Health care quality indicators on the management of rheumatoid arthritis and osteoarthritis: a literature review. Rheumatology. 2013;52(2):382-90.

32. Delnoij DM, Rademakers JJ, Groenewegen PP. The Dutch consumer quality index: an example of stakeholder involvement in indicator development. BMC Health Services Research. 2010;10(1):88.

33. Bresick G, Sayed A-R, le Grange C, Bhagwan S, Manga N. Adaptation and cross-cultural validation of the United States Primary Care Assessment Tool (expanded version) for use in South Africa. African journal of primary health care family medicine. 2015;7(1):1-11.

34. Jeon K-Y. Cross-cultural adaptation of the US consumer form of the short Primary Care Assessment Tool (PCAT): the Korean consumer form of the short PCAT (KC PCAT) and the Korean standard form of the short PCAT (KS PCAT). Qual Prim Care. 2011;19(2):85-103.

35. Dullie L, Meland E, Hetlevik $\varnothing$, Mildestvedt T, Gjesdal S. Development and validation of a Malawian version of the primary care assessment tool. BMC Fam Pract. 2018;19(1):63.

36. Hoa NT, Tam NM, Peersman W, Derese A, Markuns JF. Development and validation of the Vietnamese primary care assessment tool. PLoS One. 2018;13(1):e0191181.

37. Campbell S, Braspenning Ja, Hutchinson A, Marshall M. Research methods used in developing and applying quality indicators in primary care. Quality Safety in Health Care. 2002;11(4):358-64.

38. Brook RH, McGlynn EA, Cleary PD. Measuring quality of care. Mass Medical Soc; 1996.

39. Rubin HR, Pronovost P, Diette GB. Methodology Matters. From a process of care to a measure: the development and testing of a quality indicator. Int $\mathrm{J}$ Qual Health Care. 2001;13(6):489-96.

40. Westby MD, Klemm A, Li LC, Jones CA. Emerging role of quality indicators in physical therapist practice and health service delivery. Physical therapy. 2016;96(1):90-100.

41. Hick JL, Biddinger PD. Novel coronavirus and old lessons-preparing the health system for the pandemic. N Engl J Med. 2020;382(20):e55.

42. Flaatten $\mathrm{H}$. The present use of quality indicators in the intensive care unit. Acta anaesthesiologica scandinavica. 2012;56(9):1078-83.

43. Grace SL, Poirier P, Norris CM, Oakes GH, Somanader DS, Suskin N. Pan-Canadian development of cardiac rehabilitation and secondary prevention quality indicators. Can J Cardiol. 2014;30(8):945-8. 
44. Tricco AC, Lillie E, Zarin W, O'Brien K, Colquhoun $\mathrm{H}$, Kastner M, et al. A scoping review on the conduct and reporting of scoping reviews. BMC medical research methodology. 2016;16(1):15.

\section{Figures}

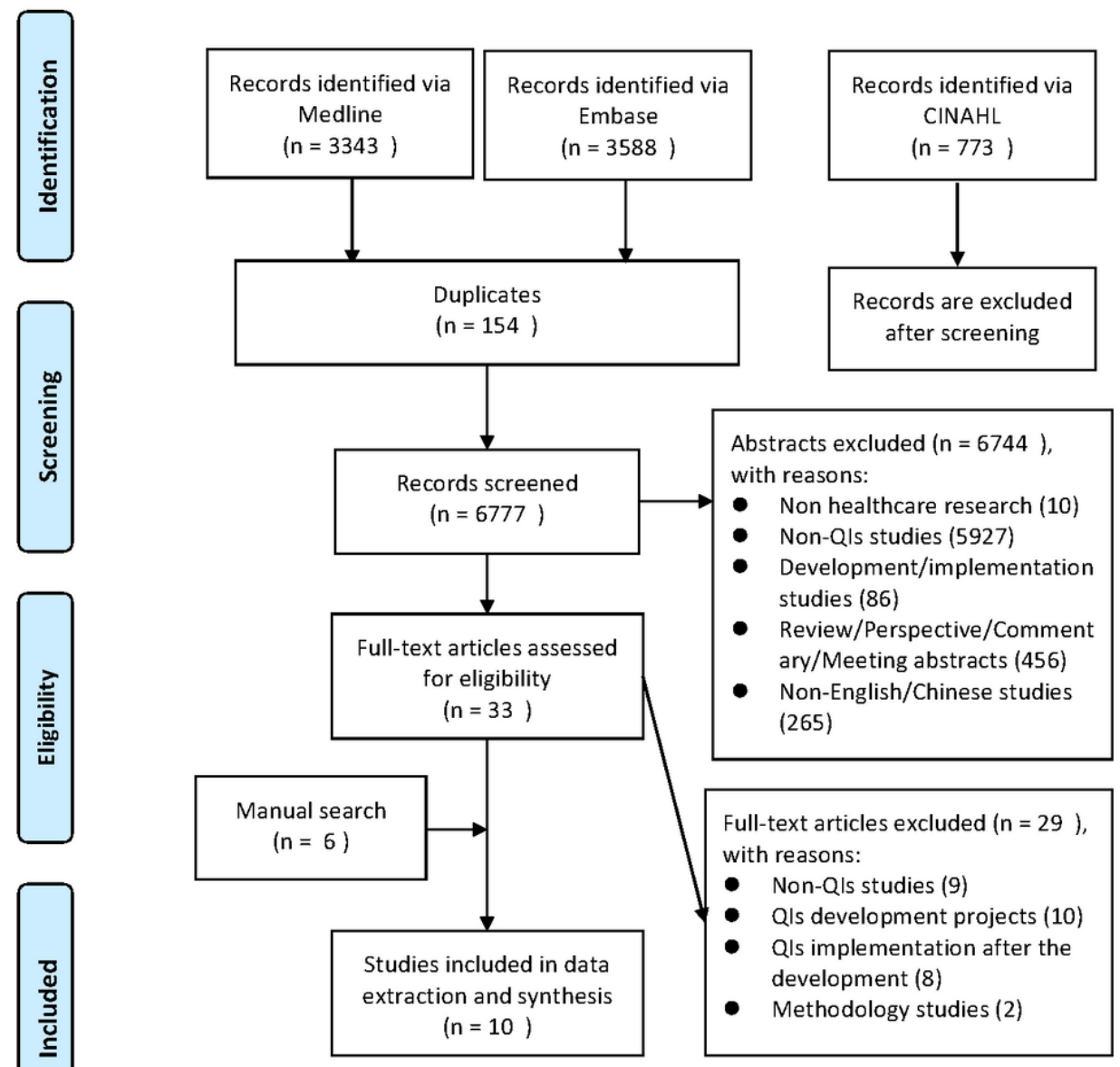

Figure 1

Flow diagram for study inclusion. 


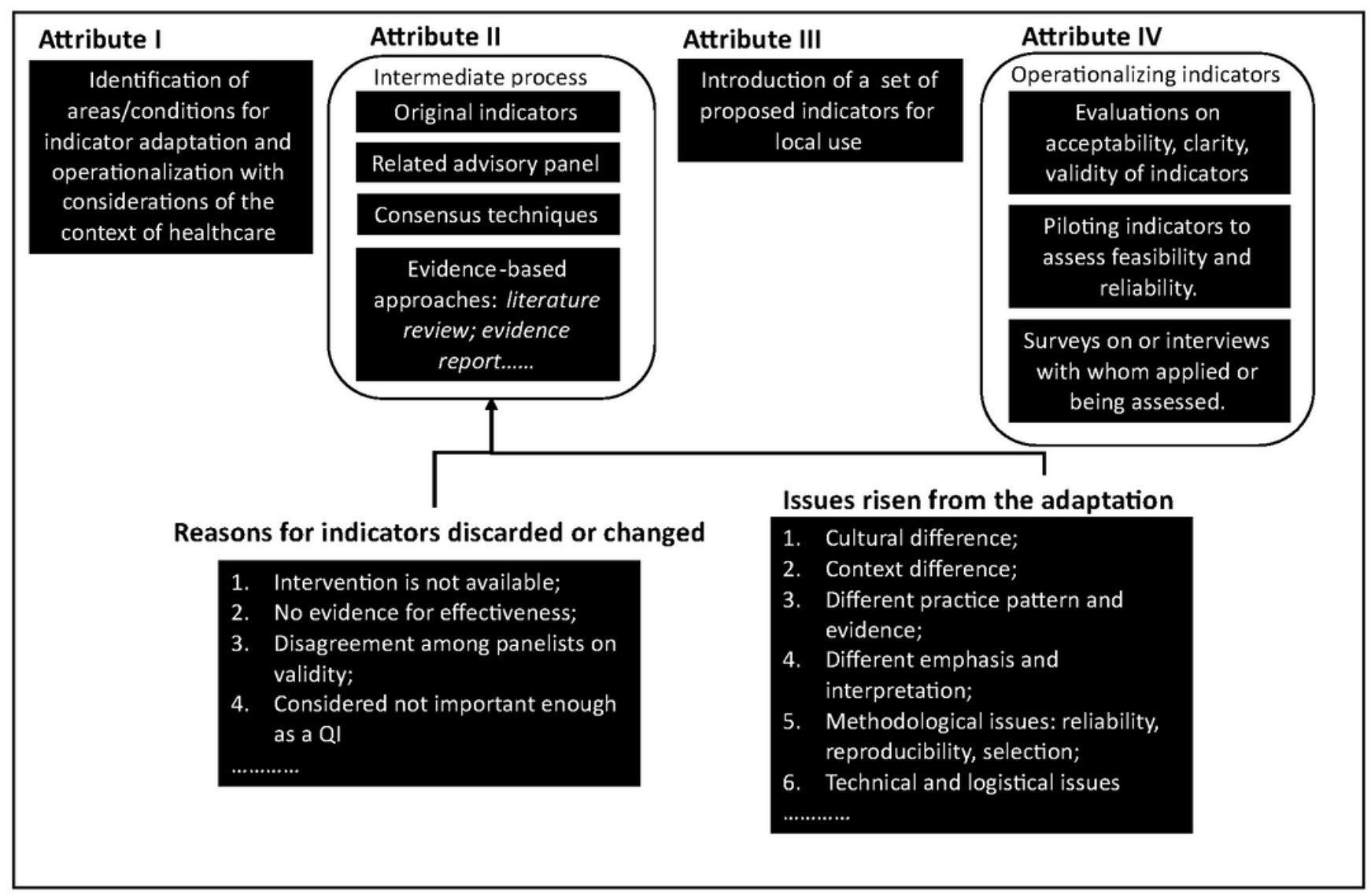

Figure 2

Map of attributes for adaptation process.

\section{Supplementary Files}

This is a list of supplementary files associated with this preprint. Click to download.

- SupplementarymaterialsV2TWSY.docx 